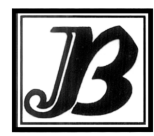

J. Bio-Sci. 27: 89-99, 2019

ISSN 1023-8654

http://www.banglajol.info/index.php/JBS/index

DOI: https://doi.org/10.3329/jbs.v27i0.44674

\title{
AN EFFICIENT REGENERATION SYSTEM THROUGH IN VITRO SOMATIC EMBRYOGENESIS OF BARLEY (HORDEUM VULGARE L.)
}

\author{
M Haque and SMS Islam* \\ Plant Biotechnology and Genetic Engineering Lab., Institute of Biological Sciences, University of Rajshahi, \\ Rajshahi-6205, Bangladesh
}

\begin{abstract}
This study was carried out to improve an efficient protocol for in vitro callus induction and plant regeneration using Bangladeshi barley genotypes collected from BARI, Gazipur, Bangladesh. After sterilization embryos were separated carefully from mature seeds of six barley genotypes (BB-1, BB-2, BB-3, BB-4, BB-5 and BB-6) and cultured them in MS medium supplemented with various concentration and combination of PGRs for callus induction and regeneration. Out of six genotypes BB-6 showed highest (38.17\%) callus induction in MS + $4.0 \mathrm{mg} / \mathrm{l} 2,4-\mathrm{D}+200 \mathrm{mg} / \mathrm{l} \mathrm{L-proline}+300 \mathrm{mg} / \mathrm{l}$ casein hydrolysate; whereas, BB-4 and BB-5 showed no callus induction in the same medium. For plant regeneration from embryogenic calli the same genotype (BB-6) also performed the best results $(19.25 \%)$ in MS medium supplemented with $1.5 \mathrm{mg} / \mathrm{l} \mathrm{BAP}+30 \mathrm{~g} / \mathrm{l}$ sucrose. Analysis of variance (ANOVA) showed highly significant differences among the media and the genotypes.
\end{abstract}

Key words: Barley, Callus, Genotypes, Plant growth regulators, Regeneration

\section{Introduction}

Somatic embryogenesis is a development process of cells, which resembles morphologically zygotic embryogenesis (De Silva et al. 2009). It is an important pathway for regeneration of plants from cell culture system and a method commonly used in a large scale production of plants (Gniech-Karasawa 2017). Steward et al. (1958) described the asexual embryogenesis (somatic embryos) in carrot, which provided a powerful technique for the mass production of artificial embryos. There are some reports on plant regeneration via somatic embryogenesis in various crop plants (Mamun et al. 2002, Neto et al. 2003, Paul et al. 2013, Rahman et al. 2015, Saha et al. 2017). Many workers have emphasized somatic embryogenesis as a preferred method for genetic improvement and multiplication of valuable germplasm of a number of woody perennials (Gupta and Durzan 1987, Bhansali 1990, Islam and Bhattacharjee 2015). The totipotent character of plant cells that retains its nucleus has the ability to regenerate entire new plant by somatic embryogenesis (SE) or organogenesis (Fortes and Pais 2000). Since somatic embryo cultures often originate from a single cell, it is an ideal system for induction of mutations as it helps in preventing chimeras. The rate of somatic embryo germination is very poor, which has become major hurdle for large-scale plant multiplication of desirable induced mutants (Dahleen and Bregitzer 2002, Lazaridou et al. 2011). Siddique et al. (2014) reported that Bangladeshi indica rice varieties viz. BR10, BRRI dhan32 and BRRI dhan47 produced high frequency of callus induction through somatic embryogenesis. The multiplication of true type plants through somatic embryogenesis is very much helpful in propagating elite and new genotypes in shorter periods of time.

*Author for correspondence: shahin_ibsc@ru.ac.bd 
Maximum barley cultivars are often considered as less responsive to tissue culture due to poor callus induction, low frequency of embryogenesis and lesser percentage of plant regeneration (Chauhan and Kothari 2004, Morshed et al. 2014, Haque and Islam 2015). Plant regeneration in barley through in vitro culture is highly genotype dependent reported by Castillo et al. (1998) and Han et al. (2011). Therefore, screening for highly responsive in vitro genotypes is very important for advance biotechnological work in barley. The process of somatic embryogenesis is not only important for the production of plants and secondary products, but also important for the transgenic plants development with desire characters. Somatic embryogenesis also plays an important role in clonal propagation. When integrated with conventional breeding programs and molecular and cell biological techniques, somatic embryogenesis provides a valuable tool to enhance the pace of genetic improvement of commercial crop species (Stasolla and Yeung 2003). The main objective of this study was to improve somatic embryogenesis as well as screening of suitable barley genotypes in Bangladesh using mature embryos.

\section{Materials and Methods}

Mature seeds of six barley genotypes viz. BARI barley-1 (BB-1), BARI barley-2 (BB-2), BARI barley-3 (BB-3), BARI barley-4 (BB-4), BARI barley-5 (BB-5) and BARI barley-6 (BB-6) were considered as plant materials for this study.

\section{Sterilization and inoculation}

Seeds were collected from Bangladesh Agricultural Research Institute (BARI), Gazipur, Bangladesh. Seeds were sterilized with $70 \%$ (v/v) ethanol for 1 minute and washed three times with sterile distilled water then treated with $0.12 \% \mathrm{NaOCl}$ for 30 minutes followed with three washes with sterile distilled water under aseptic condition. After disinfection, mature seeds were cultured in MS (Murashige and Skoog 1962) medium for callus induction.

\section{Callus induction}

For primary callus induction, MS medium supplemented with different concentrations and combination of 2,4D, BAP, L-proline, casein hydrolysate and $3 \%$ sucrose (w/v) are shown in Table 1. Under this study the six barley genotypes and twelve (12) media combination were used as per the PGRs and other components. The cultured petri dishes were incubated in the dark at $25 \pm 2^{\circ} \mathrm{C}$. After four weeks of culture initiation data were recorded on the basis of number of mature embryos induction.

Percentage of callus formation $=\frac{\text { Mature embryos formed callus }}{\text { Total number of embryos cultured }} \times 100$

Friable and compact calli were assumed as potentially embryogenic (considered as effective callus) and were selected for maintenance and regeneration. 
Table 1. MS medium along with various concentrations and combinations for PGRs, L-proline and CA for callus induction of barley genotypes

\begin{tabular}{c|c|c|c|c}
\hline Medium & $\begin{array}{c}2,4-\mathrm{D} \\
(\mathrm{mg} / \mathrm{l})\end{array}$ & $\begin{array}{c}\text { BAP } \\
(\mathrm{mg} / \mathrm{l})\end{array}$ & $\begin{array}{c}\text { L-Proline } \\
(\mathrm{mg} / \mathrm{l}\end{array}$ & $\begin{array}{c}\text { Casein hydrolysate (CA) } \\
(\mathrm{mg} / \mathrm{l})\end{array}$ \\
\hline $\mathrm{MS}+\mathrm{CIM}_{1}$ & 1.0 & - & 100 & 150 \\
$\mathrm{MS}+\mathrm{CIM}_{2}$ & 1.0 & - & 200 & 300 \\
$\mathrm{MS}+\mathrm{CIM}_{3}$ & 1.0 & - & 300 & 450 \\
$\mathrm{MS}+\mathrm{CIM}_{4}$ & 2.5 & 0.1 & 100 & 150 \\
$\mathrm{MS}+\mathrm{CIM}_{5}$ & 2.5 & 0.1 & 200 & 300 \\
$\mathrm{MS}+\mathrm{CIM}_{6}$ & 2.5 & 0.1 & 300 & 450 \\
$\mathrm{MS}+\mathrm{CIM}_{7}$ & 4.0 & - & 100 & 150 \\
$\mathrm{MS}+\mathrm{CIM}_{8}$ & 4.0 & - & 200 & 300 \\
$\mathrm{MS}+\mathrm{CIM}_{9}$ & 4.0 & - & 300 & 450 \\
$\mathrm{MS}+\mathrm{CIM}_{10}$ & 5.5 & 0.2 & 100 & 150 \\
$\mathrm{MS}+\mathrm{CIM}_{11}$ & 5.5 & 0.2 & 200 & 300 \\
$\mathrm{MS}+\mathrm{CIM}_{12}$ & 5.5 & 0.2 & 300 & 450 \\
\hline
\end{tabular}

\section{Embryogenic callus formation}

After 4 weeks of culture, primary callus of three barley genotypes (BB-1, BB-3 and BB-6) were separated from explants and transferred them to $\mathrm{ClM}_{4}(\mathrm{MS}+2.5 \mathrm{mg} / \mathrm{l} 2,4-\mathrm{D}+0.1 \mathrm{mg} / \mathrm{l} \mathrm{BAP}+100 \mathrm{mg} / \mathrm{l} \mathrm{L}-$ proline + 150 $\mathrm{mg} / \mathrm{l}$ casein) for embryogenic callus development. Data were recorded after 3 weeks of incubation and percentages of embryogenic calli $(E C)$ were evaluated.

\section{Plant regeneration}

Under this study three barley genotypes (BB-1, BB-3 and BB-6) as well as nine different concentration and combinations of MS media viz. RM $\left(\mathrm{MS}+0.5 \mathrm{mg} / \mathrm{BAP}+20 \mathrm{~g} / \mathrm{l}\right.$ sucrose), $\mathrm{RM}_{2}(\mathrm{MS}+1.0 \mathrm{mg} / \mathrm{l} \mathrm{BAP}+20 \mathrm{~g} / \mathrm{l}$ sucrose), $\mathrm{RM}_{3}\left(\mathrm{MS}+1.5 \mathrm{mg} / \mathrm{l} \mathrm{BAP}+20 \mathrm{~g} / \mathrm{l}\right.$ sucrose), $\mathrm{RM}_{4}(\mathrm{MS}+2.0 \mathrm{mg} / \mathrm{l} \mathrm{BAP}+20 \mathrm{~g} / \mathrm{l}$ sucrose $), \mathrm{RM}_{5}(\mathrm{MS}+$ $0.5 \mathrm{mg} / \mathrm{BAP}+30 \mathrm{~g} / \mathrm{l}$ sucrose), $\mathrm{RM} 6$ (MS + $1.0 \mathrm{mg} / \mathrm{BAP}+30 \mathrm{~g} / \mathrm{l}$ sucrose), $\mathrm{RM}$ ( $(\mathrm{MS}+1.5 \mathrm{mg} / \mathrm{BAP}+30 \mathrm{~g} / \mathrm{l}$ sucrose), $\mathrm{RM}_{8}(\mathrm{MS}+2.0 \mathrm{mg} / \mathrm{BAP}+30 \mathrm{~g} / \mathrm{l}$ sucrose) and $\mathrm{RM}$ ( $\mathrm{MS}+1.5 \mathrm{mg} / \mathrm{l} \mathrm{BAP}+40 \mathrm{~g} / \mathrm{l}$ sucrose) were used and evaluted their regeneration efficiency. In all cases, 2-3\% (w/v) sucrose was used as carbon sources. Cultures were maintained at $25^{\circ} \mathrm{C}$ with $16 / 8 \mathrm{~h}$ (light/dark) and regeneration frequency was evaluated after 4 weeks of incubation in regeneration medium. Regenerated shoots were transferred to half-strength of MS medium that supplemented with $20 \mathrm{~g} / \mathrm{l}$ sucrose and $2.0 \mathrm{mg} / \mathrm{l} \mathrm{NAA}$ for rooting. The well-rooted plants were transferred into pots. 


\section{Data recording and statistical analysis}

Each treatment contained three replications and the whole experiment was repeated three times. Statistical analysis was performed using SPSS software (version 16). Data were evaluated on the basis of primary callus induction and regeneration among the studied genotypes and evaluated those parameters by one-way analysis of variance (ANOVA). The significance of differences and comparisons between the mean values were determined by least significant difference (LSD) formulation at $5 \%$ level.

\section{Results}

For primary callus induction six barley genotypes (BB-1, BB-2, BB-3, BB-4, BB-5 and BB-6) were cultured and evaluated their efficiency using twelve different combinations of PGRs in addition with MS medium. The results indicated that BB-6 showed highest (38.17\%) percentage of callus followed by BB-3 (30.11\%) and BB-1 (24.04\%). Whereas, BB-2 showed very low (7.65\%) and BB-4 and BB-5 showed no callus induction (Fig. 1). The compact and friable calli were transferred to regeneration medium and evaluated its regeneration efficiency (Fig. 2). Analysis of variance (ANOVA) showed significantly higher results between the genotypes and culture combinations (Table 3).

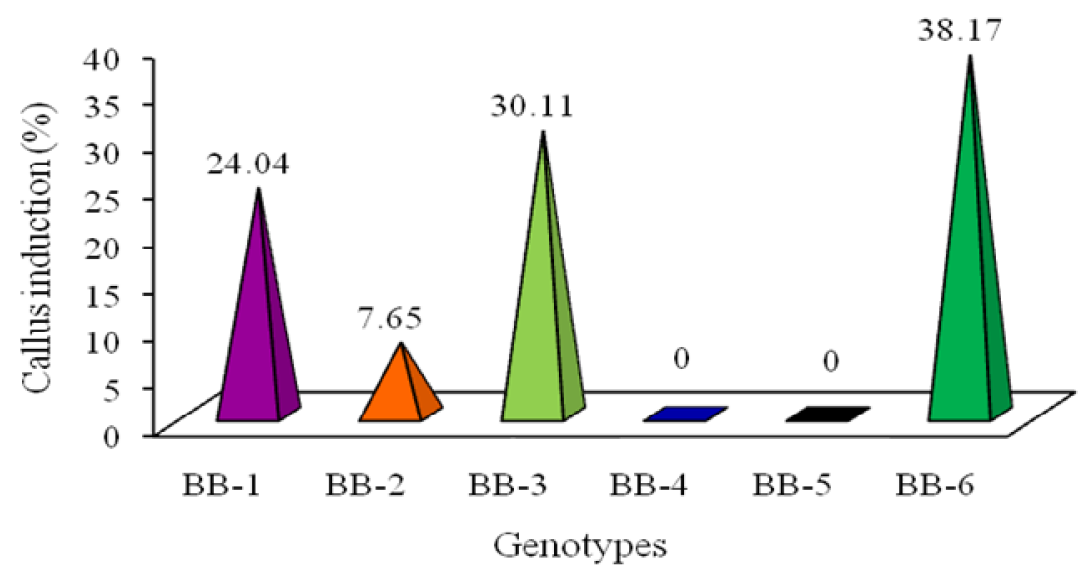

Fig. 1. Primary callus induction responses of mature embryos in six barley genotypes.

MS medium ( $\left.\mathrm{CIM}_{4}\right)$ containing $2.5 \mathrm{mg}$ 2,4-D, $0.1 \mathrm{mg} \mathrm{BAP,} 100 \mathrm{mg} / \mathrm{l}$-proline and $150 \mathrm{mg} / \mathrm{l} \mathrm{CA}$ was found to be very effective for embryogenic callus induction. The percentage of embryogenic callus was $27.49 \%$, $20.66 \%$ and $14.89 \%$ in BB-6, BB-3 and BB-1, respectively (Fig. 3). The genotype BB-6 showed the highest frequency of embryogenic callus compared with BB-3 and BB-1. In this case nodular, heart and torpedo shaped embryogenic calli gave better green plants than others (Fig. 2).

The media formulation of $\mathrm{RM}_{7}$ (MS $+1.5 \mathrm{mg} / \mathrm{BAP}+30 \mathrm{~g} / \mathrm{l}$ sucrose) showed significantly better results for regeneration than others. The highest regeneration percentages were recorded for BB-6 (19.25\%), BB-3 (13.33\%) and BB-1 (9.72\%) in RM7 mdium (Table 2). On the other hand, $\mathrm{RM}_{1}(\mathrm{MS}+0.5 \mathrm{mg} / \mathrm{lBAP}+20 \mathrm{~g} / \mathrm{l}$ sucrose) showed lowest regeneration (4.48\% for BB-6 and 3.80\% for BB-3). It was observed that the genotype BB-6 showed good regeneration (9.26\%) in terms of average number of plants per somatic embryos. Analysis of variance (ANOVA) showed highly significant differences among the media and the genotypes (Table 3). Regenerated plants were transferred to rooting medium. Then after acclimatization well-rooted plants were transferred to the soil. 

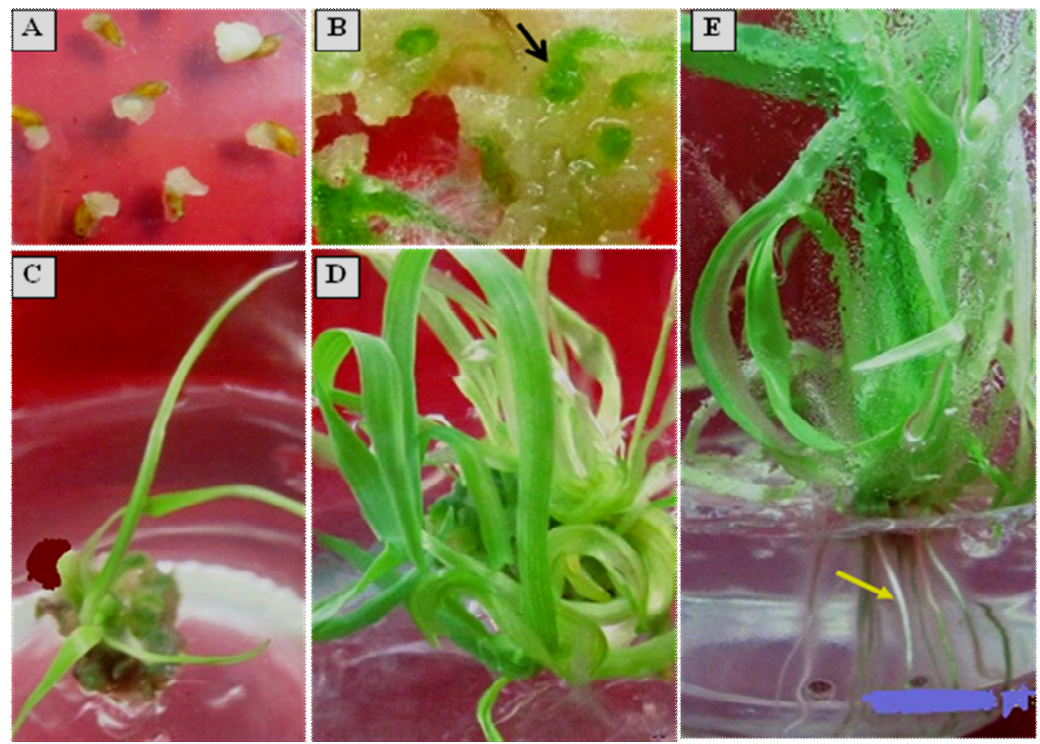

Fig. 2 (A-E). Somatic embryogenesis and plant regeneration in barley. A) Callus derived from seeds after 1 week of culture initiation, B) Embryogenic callus after 5 weeks, C) Initiation of shoots after 7 weeks of culture, D) Shoot developments after 9 weeks of culture, E) Regenerated plants with good roots and shoots after 11 weeks of culture.

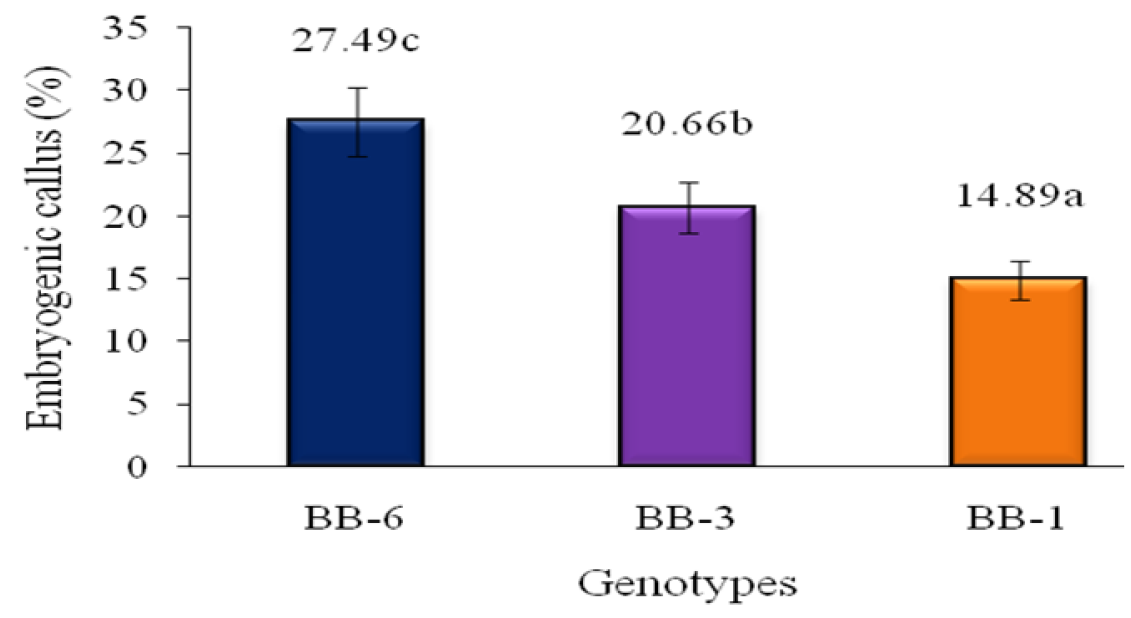

Fig. 3. Frequencies of embryogenic calli derived from mature embryos of three barley genotypes. 
Table 2. Effect of nine different RM medium on regeneration efficiency using three barley genotypes

\begin{tabular}{|c|c|c|c|c|}
\hline Genotypes & Medium & $\begin{array}{l}\text { No. of embryogenic } \\
\text { calli (cultured) }\end{array}$ & $\begin{array}{l}\text { No. of calli response } \\
\text { to regeneration }\end{array}$ & $\begin{array}{l}\% \text { of regeneration } \\
\text { (Mean } \pm \mathrm{SE})\end{array}$ \\
\hline \multirow{10}{*}{ BB-6 } & $\mathrm{RM}_{1}$ & 156 & 7 & $4.48 \pm 0.64 a$ \\
\hline & $\mathrm{RM}_{2}$ & 135 & 13 & $9.62 \pm 1.95 b c$ \\
\hline & $\mathrm{RM}_{3}$ & 135 & 14 & $10.37 \pm 1.48 \mathrm{c}$ \\
\hline & $\mathrm{RM}_{4}$ & 135 & 10 & $7.40 \pm 1.95 b$ \\
\hline & $\mathrm{RM}_{5}$ & 165 & 10 & $6.06 \pm 1.60 \mathrm{~b}$ \\
\hline & $\mathrm{RM}_{6}$ & 126 & 17 & $13.49 \pm 2.09 d$ \\
\hline & $\mathrm{RM}_{7}$ & 135 & 26 & $19.25 \pm 1.95 \mathrm{e}$ \\
\hline & $\mathrm{RM}_{8}$ & 120 & 9 & $7.5 \pm 1.44 b$ \\
\hline & $\mathrm{RM}_{9}$ & 135 & 7 & $5.18 \pm 0.74 a b$ \\
\hline & Mean & 138.00 & 12.56 & 9.26 \\
\hline \multirow{10}{*}{ BB-3 } & $\mathrm{RM}_{1}$ & 105 & 4 & $3.80 \pm 0.95 a$ \\
\hline & $\mathrm{RM}_{2}$ & 75 & 5 & $6.66 \pm 1.33 b$ \\
\hline & $\mathrm{RM}_{3}$ & 84 & 7 & $8.33 \pm 1.19 b c$ \\
\hline & $\mathrm{RM}_{4}$ & 96 & 5 & $5.20 \pm 1.04 a b$ \\
\hline & $\mathrm{RM}_{5}$ & 99 & 4 & $4.04 \pm 1.01 \mathrm{a}$ \\
\hline & $\mathrm{RM}_{6}$ & 78 & 8 & $10.25 \pm 1.28 c$ \\
\hline & $\mathrm{RM}_{7}$ & 60 & 8 & $13.33 \pm 1.66 d$ \\
\hline & $\mathrm{RM}_{8}$ & 66 & 4 & $6.06 \pm 1.51 \mathrm{ab}$ \\
\hline & $\mathrm{RM}_{9}$ & 102 & 5 & $4.90 \pm 0.98 \mathrm{ab}$ \\
\hline & Mean & 85.00 & 5.56 & 6.95 \\
\hline \multirow{10}{*}{ BB-1 } & $\mathrm{RM}_{1}$ & 24 & 0 & 0 \\
\hline & $\mathrm{RM}_{2}$ & 66 & 2 & $3.03 \pm 1.51 \mathrm{ab}$ \\
\hline & $\mathrm{RM}_{3}$ & 84 & 4 & $4.76 \pm 1.19 b$ \\
\hline & $\mathrm{RM}_{4}$ & 60 & 2 & $3.33 \pm 1.66 \mathrm{ab}$ \\
\hline & $\mathrm{RM}_{5}$ & 78 & 2 & $2.56 \pm 1.28 a b$ \\
\hline & $\mathrm{RM}_{6}$ & 61 & 4 & $6.34 \pm 1.58 \mathrm{bc}$ \\
\hline & $\mathrm{RM}_{7}$ & 72 & 7 & $9.72 \pm 1.38 \mathrm{c}$ \\
\hline & $\mathrm{RM}_{8}$ & 102 & 4 & $3.92 \pm 0.98 a b$ \\
\hline & $\mathrm{RM}_{9}$ & 126 & 2 & $1.58 \pm 0.79 a$ \\
\hline & Mean & 74.78 & 3.00 & 3.92 \\
\hline
\end{tabular}

Different letters of mean values in the same column indicate significant differences within culture combinations ( $L S D$ test, $\mathrm{p}<0.005)$. 
Table 3. Analysis of variance (ANOVA) subjected to primary callus induction for two genotypes and plant regeneration for three barley genotypes

\begin{tabular}{|c|c|c|c|c|c|}
\hline \multirow{7}{*}{ 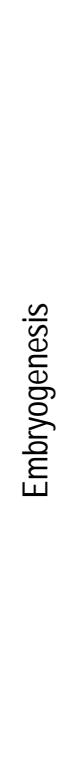 } & Variable & Source of variation & $d f$ & $\begin{array}{l}\text { Mean sum } \\
\text { of square }\end{array}$ & F. value \\
\hline & & Genotype & 5 & 85.26 & $18.14^{\star *}$ \\
\hline & Callus induction & Culture combination & 11 & 41.08 & $19.57^{* *}$ \\
\hline & & $\begin{array}{l}\text { Genotype } \times \text { culture } \\
\text { combination }\end{array}$ & 11 & 6.23 & - \\
\hline & & Genotype & 2 & 64.69 & $49.02^{* *}$ \\
\hline & Plant regeneration & Media formulation & 8 & 37.28 & $28.26^{\star *}$ \\
\hline & & $\begin{array}{l}\text { Genotype } \times \text { media } \\
\text { formulation }\end{array}$ & 16 & 1.31 & - \\
\hline
\end{tabular}

** = significant at $1 \%$ level of probability.

\section{Discussion}

Plants regeneration is very essential for establishing a successful tissue culture system. In case of tissue culture for all crops do not show equal regeneration ability. Sometimes it is very difficult to culture and regenerate agronomically important crops (Puhan and Siddiq 2013). Somatic embryogenesis is a multi-step regeneration process starting with formation of pro-embryogenic masses, followed by somatic embryo formation, maturation and plant regeneration (Arnold et al. 2002, Sharmin et al. 2014). The difference in the composition of culture medium and the concentrations of hormones affect the callus induction and regeneration ability of barley and other plant genotypes (Tariq et al. 2008, Haque and Islam 2014). As auxin 2,4-D is very important and required for the production of somatic embryogenesis in cereal crops (Armstrong et al. 1987, Nasircilar et al. 2006). Somatic embryos are formed on nutrient medium with a reduced 2,4-D concentration is reported by Delporte et al. (2001). Furthermore, genotype variation also plays a vital role in callus initiation, proliferation and even regeneration in barley (Gubišová et al. 2012) and rice (Khanna and Raina 1998).

In this study, twelve different concentration and combinations of PGRs were used with MS medium and found that significant differences between media components. It was observed that $4.0 \mathrm{mg} / \mathrm{l} 2,4-\mathrm{D}+200 \mathrm{mg} / \mathrm{l}$ L-proline and $300 \mathrm{mg} / \mathrm{l}$ casein hydrolysate promoted callus induction in barley. However, increasing amount of 2,4-D from $1 \mathrm{mg} / \mathrm{l}$ to $4.0 \mathrm{mg} / \mathrm{l}$ showed significantly highest percentages of callus induction. The culture combination of $\mathrm{CIM}_{8}$ contained MS $+4.0 \mathrm{mg} / \mathrm{l}$ 2,4-D $+200 \mathrm{mg} / \mathrm{l} \mathrm{L-proline}+300 \mathrm{mg} / \mathrm{l}$ casein hydrolysate gave best primary callus induction when used mature embryos as explants. Chernobrovkina et al. (2004) studied 
with addition of L-proline $(160 \mathrm{mg} / \mathrm{l})$ showed negative impact on the in vitro embryo culture in barley. Aguado-Santacruz et al. (2011) demonstrated that $2 \mathrm{mg} / \mathrm{l}$ of 2,4-D showed better callus induction. Whereas, in addition of amino acid with higher concentrations $(230 \mathrm{mg} / \mathrm{l})$ did not show any callus induction. Till several protocols for in vitro callus culture of barley and other crops have been successfully developed by Lupotto (1984), Bregitzer (1992), Castillo et al. (2000), Chauhan and Kothari (2004), Asakavičiūtè and Pašakinskienè (2006), Gubišová et al. (2012), Haque and Islam (2014), Mrízová et al. (2014), Haque and Islam (2015). However, only a few barley genotypes have been identified that possesses good regeneration capacity (Lemaux et al. 1999, Aguado-Santacruz et al. 2011). Suitable barley response to in vitro culture with highest regeneration potential and correct explants as well as their proper developmental stage to be used as genetic transformation (Chang et al. 2003, Kasha 2007). It was reported that mature (Sharma et al. 2005, Yadav et al. 2011) and immature embryos (Walmsley et al. 1995, Haque and Islam 2015) were suitable explants for somatic embryogenesis in barley and other cereal crops. Under this study, successfully induced callus from mature embryos of some barley genotypes using MS medium. The medium was supplemented with different concentrations of 2,4-D, L-proline and casein hydrolysate. The results obtained in this study are quite similar with the report of Ganeshan et al. (2003), who successfully induced callus from mature embryo of barley. They used similar components in the medium (2,4-D, L-proline and casein hydrolysate) but the concentration was different with the present findings.

Various concentration and combination of auxins, cytokinins play an important role for embryogenic callus induction in barley reported by Serhantova et al. (2004). The present results showed that MS $+2.5 \mathrm{mg} / \mathrm{l} 2,4$ $\mathrm{D}+0.1 \mathrm{mg} / \mathrm{l} \mathrm{BAP}+100 \mathrm{mg} / \mathrm{l} \mathrm{L}-\mathrm{proline}+150 \mathrm{mg} / \mathrm{l}$ casein hydrolysate was adequate for embryogenic callus formation. Walmsley et al. (1995) stated that $2.0 \mathrm{mg} / \mathrm{l}$ of 2,4-D was suitable for initiation of embryogenic callus in barley. Bregitzer et al. (1998) reported that the formation of embryogenic callus in various barley genotypes was depended on 2,4-D concentration, and 2-3 mg/l was adequate in most of the cases. Amali et al. (2014) demonstrated that the addition of L-proline considerably improved the somatic embryo formation in MS medium containing $2.5 \mathrm{mg} / \mathrm{l}$ 2,4-D and $500 \mathrm{mg} / \mathrm{l}$ casein hydrolysate in sorghum. Casein hydrolysate can be used as a relatively cheap source of a mixture of amino acids (Slater et al. 2003). In addition of amino acids in the medium serve as a source of reduced nitrogen required for plant metabolism and growth. The present study revealed that the addition of casein hydrolysate to the medium enhanced embryogenic callus formation in barley.

In this study plant regeneration efficiency were tested and for that nine regeneration media were used that contained MS basal medium with different concentrations of BAP and sucrose. The present results demonstrated that regeneration formulation of $\mathrm{RM}_{7}(\mathrm{MS}+1.5 \mathrm{mg} / \mathrm{BAP}+30 \mathrm{~g} / \mathrm{l}$ sucrose) functioned better than others. This result agreed well with previous works where the MS medium and BAP were successfully used in barley (Aguado-Santacruz et al. 2011). There are some reports on the effect of sucrose was scrutinized on induction of plant (Shah et al. 2014). A similar type of result was found by Lee et al. (2012). They reported that sucrose has been commonly used at the concentration of 20 and $30 \mathrm{~g} / \mathrm{l}$ as a carbon source in tissue culture medium. But they have not found any combined effect of different concentrations of BAP and sucrose for regeneration purpose. In this case BB-6 showed particularly high stability in callus induction over the different culture combination and higher regeneration compared to BB-3 and BB-1. However, this results proven that embryogenic callus formation and plant regeneration ability are depends using a suitable genotype. 


\section{References}

Aguado-Santacruz GA, Velázquez-Ordinola Á, Moreno-Gómez B, Gómez-Torres LM, Díaz-Espino LF and Vázquez FPG (2011). Development of long-term and reliable in vitro plant regeneration systems for elite malting barley varieties: Optimizing media formulation and explant selection. African Journal of Biotechnology, 10(84): 19522-19533.

Amali P, Kingsley SJ and Ignacimuthu S (2014). Enhanced plant regeneration involving somatic embryogenesis from shoot tip explants of Sorghum bicolor (L. Moench). Asian Journal of Plant Science and Research, 4(3): 26-34.

Armstrong TA, Metz SG and Mascia PN (1987). Two regeneration system for the production of haploid plants from wheat anther culture. Plant Sci., 51: 231-237.

Arnold von S, Sabala I, Bozhkov P, Dyachok J and Filonova L (2002). Developmental pathways of somatic embryogenesis. Plant Cell, Tiss. Org. Cult., 69: 233-249.

Asakavičiūtè $\mathrm{R}$ and Pašakinskienè $\mathrm{H}$ (2006). Androgenesis in anther culture of Lithuanian spring barley cultivars. Biologia, 4: 37-40.

Bhansali R (1990). Somatic embryogenesis and regeneration of plantlets in pomegranate. Annals of Bot., 66: 249-253.

Bregitzer P (1992). Plant regeneration and callus type in barley: effects of genotype and culture medium. Crop Science, 32: 1108-1112.

Bregitzer P, Dahleen LS and Campbell RD (1998). Enhancement of plant regeneration from embryogenic callus of commercial barley cultivars. Plant Cell Rep., 17: 941-945.

Castillo AM, Egana B, Sanz JM and Cistué L (1998). Somatic embryogenesis and plant regeneration from barley cultivars grown in Spain. Plant Cell Rep., 17: 902-906.

Castillo AM, Valles MP and Cistué L (2000). Comparison of anther and isolated microspores cultures in barley. Effects of culture density and regeneration medium. Euphytica, 113: 1-8.

Chang Y, Von Zitzewitz J, Hayes PM and Chen THH (2003). High frequency plant regeneration from immature embryos of an elite barley cultivar (Hordeum vulgare L. cv. Morex). Plant Cell Reports, 21: 733-738.

Chauhan M and Kothari SL (2004). Optimization of nutrient levels in the medium increases the efficiency of callus induction and plant regeneration in recalcitrant Indian barley (Hordeum vulgare L.) in vitro. In vitro Cellular and Developmental Biology-Plant, 40: 520-527.

Chernobrovkina MA, Karavaev CA, Kharchenko PN and Melik-Sarkisov OS (2004). Somatic embryogenesis and morphogenetic potential of spring barley (Hordeum vulgare L.) in the system of technological genetic transformation. Biological Bulletin, 31: 332-336.

Dahleen LS and Bregitzer P (2002). An improved media system for high regeneration rates from barley immature embryo-derived callus cultures of commercial cultivars. Crop Science, 42: 934-938.

De Silva ML, Pinto DLP, Guerra MP, Floh EIS, Bruckner CH and Otoni WC (2009). A novel regeneration system for a wild passion fruit species (Passiflora cincinnata Mast.) based on somatic embryogenesis from mature zygotic embryos. Plant Cell, Tissue and Organ Culture, 99: 47-54.

Delporte $F$, Mostade $O$ and Jacquemın JM (2001). Plant regeneration through callus initiation from thin mature embryo fragments of wheat. Plant Cell, Tissue and Organ Culture, 67: 73-80.

Fortes AM and Pais MS (2000). Organogenesis from internode-derived nodules of Humulus lupulus L. var. Nugget (Cannabinaceae): histological studies and changes in the starch content. Am. J. Bot., 7: 971-979.

Ganeshan S, Baga M, Harvey BL, Rossnagel BG, Scoles GJ and Chibbar RN (2003). Production of multiple shoots from thidiazuron-treated mature embryos and leaf base/apical meristems of barley (Hordeum vulgare). Plant Cell, Tissue and Organ Culture, 73: 57-64. 
Gniech-Karasawa MM (2017). Gametic embryogenesis, somatic embryogenesis, plant cell cultures, and protoplast fusion: Progress and Opportunities in Biofuel Production. DOI: 10.2174/9781681084619117010004.

Gubišová M, Mihálik D and Gubiš J (2012). Optimization of barley mature embryo regeneration and comparison with immature embryos of local cultivars. Nova Biotechnologica Chimica, 11(1): 57-62.

Gupta PK and Durzan DJ (1987). Biotechnology and somatic polyembryogenesis and plantlet regeneration in loblolly pine. Bio/Technology, 5: 147-151.

Han $Y$, Jin X, Wu F and Zhang G (2011). Genotypic differences in callus induction and plant regeneration from mature embryos of barley (Hordeum vulgare L.). Journal of Zheijang University Science B (Biomedicine \& Biotechnology), 12(5): 399-407.

Haque M and Islam SMS (2014). Enhancement of anther culture response by cold pretreatment and optimization of media about two barley (Hordeum vulgare L.) genotypes derived from Bangladesh. Asia-Pacific Journal of Molecular Biology and Biotechnology, 22(1): 127-136.

Haque M and Islam SMS (2015). Callus age and size of barley (Hordeum vulgare L.) improves regeneration efficiency. Notulae Scientia Biologicae, 7(2): 188-191.

Islam SMS and Bhattacharjee B (2015). Plant regeneration through somatic embryogenesis from leaf and root explants of Rhynchostylis retusa (L.) Blume. Applied Biological Research, 17(2): 158-165.

Kasha KJ (2007). Barley. In: Pua EC, Davey MR (Eds.) Transgenic crops IV. Springer, Berlin Heidelberg, New York, Vol. 59, pp. 129-149.

Khanna HK and Raina SK (1998). Genotype $\times$ culture media interaction effects on regeneration response of three indica rice cultivars. Plant Cell, Tissue and Organ Culture, 52: 145-153.

Lazaridou TB, Sistanis I, Lithourgidis A, Ambrus H and Roupakias D (2011). Response to in vitro anther culture of $F_{3}$ families originating from high and low yielding $F_{2}$ barley (Hordeum vulgare L.) plants. Aus. J. Crop Sci., 5(3): 265270.

Lee KW, Chinzorig O, Choi GJ, Kim KY, Ji HC, Park HS, Kim WH and Lee SH (2012). Factors influencing callus induction and plant regeneration of Dahurian wildrye grass (Elymus dahuricus L.). Afr. J. Biotech., 11(4): 815-820.

Lemaux P, Cho M, Zhang S and Bregitzer P (1999). Transgenic cereals: Hordeum vulgare L. (barley). In: Vasil IK (ed) Molecular improvement of cereal crops. Advances in cellular and molecular biology of plants. Kluwer Academic Publisher, Dordrecht, Boston, London, 5: 255-316.

Lupotto E (1984). Callus induction and plant regeneration from barley mature embryos. Annals of Botany, 54: 523-529.

Mamun ANK, Islam SMS and Bari MA (2002). Micropropagation of some woody legumes through tissue culture technique. In: Proceedings of the International Workshop of BIO-REFOR, Tokyo, Japan, Oct. 7-11, pp. 139-144.

Morshed S, Siddique AB and Islam SMS (2014). Efficient plant regeneration using mature and immature embryos of maize (Zea mays L.). International Journal of Agriculture Innovations and Research, 3(3): 895-904.

Mrízová K, Holasková E, Tufan Öz M, Jiskrová E, Frébort I and Galuszka P (2014). Transgenic barley: A prospective tool for biotechnology and agriculture. Biotechnology Advances, 32(1): 137-157.

Murashige T and Skoog F (1962). A revised medium for rapid growth and bioassays with tobacco tissue cultures. Physiologia Plantarum, 15: 473-497.

Nasircilar AG, turgut K and Fiskin K (2006). Callus induction and plant regeneration from mature embryos of different wheat genotypes. Pak. J. Bot., 38(2): 637-645.

Neto VBP, Botelho MN, Aguiar R, Silva EAM and Otoni WC (2003). Somatic embryogenesis from immature zygotic embryos of Annatto (Bixa orellana L.). In Vitro Cellular and Developmental Biology-Plant, 39(6): 629-634. 
Paul KK, Bari MA, Islam SMS and Debnath SC (2013). In vitro shoot regeneration in Elephant Foot Yam, Amorphophallus campanulatus Blume. Plant Tissue Culture and Biotechnology, 20(1): 55-61.

Puhan P and Siddiq EA (2013). Protocol optimization and evaluation of rice varieties response to in vitro regeneration. Adv. Biosci. Biotech., 4: 647-653.

Rahman MZ, Islam SMS, Chowdhury AN and Subramaniam S (2015). Efficient microtuber production of potato in modified nutrient spray bioreactor system. Scientia Horticulturae, 192: 369-374.

Serhantova V, Ehrenbergerova J and Ohnoutkova L (2004). Callus induction and regeneration efficiency of spring barley cultivars registered in the Czech Republic. Plant Soil and Environment, 50: 456-462.

Saha S, Islam Z, Islam S, Hassan MF, Hossain MS and Islam SMS (2017). Enhancement of somatic embryogenesis by mature and immature seeds in wheat (Triticum aestivum L.). Journal of Biology and Life Science, 8(2): 20-31.

Shah SH, Ali S, Jan SA and Ali GM (2014). Assessment of carbon sources on in vitro shoot regeneration in tomato. Pak. J. Agr. Sci., 51(1): 197-207.

Sharma VK, Hänsch R, Mendel RR and Schulze J (2005). Mature embryo axis-based high frequency somatic embryogenesis and plant regeneration from multiple cultivars of barley (Hordeum vulgare L.). J. Exp. Bot., 56: 1913-1922.

Sharmin SA, Alam MJ, Sheikh MMI, Sarker KK, Khalekuzzaman M, Haque MA, Alam MF and Alam I (2014). Somatic embryogenesis and plant regeneration in Wedelia calendulacea Less. An endangered medicinal plant. Brazilian Archives of Biology and Technology, 57(3): 394-401.

Siddique AB, Ara I, Islam SMS and Tuteja N (2014). Effect of air desiccation and salt stress factors on in vitro regeneration of rice (Oryza sativa L.). Plant Sig. Behav., 9(12): e977209-1-10.

Slater A, Scott N and Fowler M (2003). The genetic manipulation of plants, Plant Biotechnology- Oxford University Press, pp. 346.

Stasolla C and Yeung EC (2003). Recent advances in conifer somatic embryogenesis: improving somatic embryos quality. Plant Cell, Tissue and Organ Culture, 74: 15-35.

Steward FC, Mapes MO and Smith J (1958). Growth and organized development of cultured cells. I. Growth and division of freely suspended cells. Am. J. Bot.., 45: 693-703.

Tariq M, Ali G, Hadi F, Ahmed S, Ali N and Shah AA (2008). Callus induction and in vitro plant regeneration of rice (Oryza sativa L.) under various conditions. Pakistan Journal of Biological Sciences, 11(2): 255-259.

Walmsley A, Henry R and Birch R (1995). Optimization of tissue culture conditions for transformation studies using immature embryos of Australian barley cultivars. Australian Journal of Botany, 43: 499-504.

Yadav T, Kothari SL and Kachhwaha S (2011). Evaluation of regeneration potential of mature embryo derived callus in Indian cultivars of barley (Hordeum vulgare L.). Journal of Plant Biochemistry and Biotechnology, 20(2): 166-172.

(Manuscript received on July 07, 2018 and revised on December 12, 2018) 